\title{
THE IMPORTANCE OF EDUCATIONAL TECHNOLOGY IN TEACHING
}

\author{
Dr. Lazar Stošić, College of professionals studies educators, Aleksinac Serbia \\ E-mail: 1stosic@,vsvaspitacka.edu.rs
}

Received: May, 14.2015.

Accepted: June, 01.2015.

Studies and articles

UDK 371:004

37.026

\begin{abstract}
Today, more than ever, the role of educational technology in teaching is of great importance because of the use of information and communication technologies. With the help of various applications for distance education, the Internet, teachers, and students themselves, they see the advantage of educational technology. The question is whether schools and teachers themselves are ready for the use of technology in education and whether they are aware of its benefits? In this paper, we try to give an overview of the importance and use of educational technology in the classroom.

Keywords: Educational technology, Technology and learning, School, Teachers, The impact of technology on learning.
\end{abstract}

\section{INTRODUCTION}

Educational technology is a systematic and organized process of applying modern technology to improve the quality of education (efficiency, optimal, true, etc.). It is a systematic way of conceptualizing the execution and evaluation of the educational process, i. e. learning and teaching and help with the application of modern educational teaching techniques. It includes instructional materials, methods and organization of work and relationships, i.e. the behavior of all participants in the educational process. The term "teaching resources" is commonly used, although they are not synonymous (Pedagoški leksikon, 1996). The word technology is derived from the Greek word "techno" which means the willingness, skills, knowledge of the way, rule, skill, tools and "logos" which means science, word, learning, mental state. There is no

Corresponding Author

Dr. Lazar Stošić, College of professionals studies educators, Aleksinac, Serbia

E-mail: 1stosic@vsvaspitacka.edu.rs single term for educational technology. Different countries use different terms and synonyms as educational technology, educational equipment, AV resources, the technology of teaching...

Terminological differences mostly occur on the grounds of the approach to the technical characteristics and the use of modern appliances, and not their actual application in teaching i.e. their actual pedagogical application. For this reason, there are different opinions among teachers in the field of social and technical sciences. Therefore, the application of educational technology requires knowledge from several areas: pedagogy, psychology, didactics, computer sciences, informatics... Because of this diversity, there are also different perceptions of educational technology, where every author defines the concept of educational technology, according to their needs. Educational technology is still not being applied sufficiently, mostly for reasons of lack of school equipment necessary resources and insufficient qualification of teachers for the implementation of these funds.

Educational technology has three domains of use:

- Technology as a tutor (computer gives instructions and guides the user),

- Technology as a teaching tool and

- Technology as a learning tool.

Depending on the use and benefits, the research by Lowther et al., (2012) suggests that education technology has not yet taken its place, in spite of their recommendations. This is probably the reason for the statute of the social company. Leu et al., (2009) state that children in poorer areas very rarely use the Internet as a learning tool. Today's children use modern technical equipment from an early age (Gutnik et al., 2011; Rideout 2011) so that their coming in with new educational technologies at school will not be a problem. 
In studies (Greenhow et al., 2009), we can find out that more students use modern technical equipment. Serious research on the influence of education technology on cognitive processes was conducted by Kaufman, 2004; Lee et al., (2008).

When using educational technology we should be primarily focused on the educational value of the tools and applications we use, how adequate they are in the acquisition of knowledge, whether there is an interaction between users and tools, and if we have positive effects in using them. A number of authors (Clements and Sarama, 2003; Glaubke 2007; Dynarski et al. 2007) suggest that we should focus on five areas of software programs that have the potential to strongly influence children's learning experience:

1. The educational value of the program,

2. Its ability to engage children in learning,

3. Ease of use,

4. Interactivity between the child and programs,

5. The possibility that a software program monitors the progress of the child.

\section{THE IMPORTANCE OF EDUCATIONAL TECHNOLOGY IN TEACHING}

Since computers are still not widely used in many schools, the teaching process is dominated by traditional methods. It is dominated by the frontal form of work where the teacher had enough interaction with students. Failure to thrive at their own pace and insufficient activity of students was one of the drawbacks of this type of learning. In class, we have children who are not uniform in knowledge and never pay enough attention to those who are not sufficiently mastered the material and those who are above their average. This difference is often hampered by teacher assessment work and how to transfer knowledge to a group of children with different knowledge. The teacher chooses to keep average to good teaching where children with insufficient knowledge would not get the necessary knowledge. The children with insufficient knowledge can progress smoothly without unpleasant feeling of their ignorance, no frustration, and humiliation while for the most advanced children teaching will be boring.

With the development of information and communication technology, especially computers, a number of researchers (Morri- son et al., 2010) were trying to see the benefits and the effect of their use compared to older traditional learning. For many years, we tried to give answers to the question of advantages and disadvantages between traditional and modern teaching where the prevailing educational technology. The period from 1967. to 1972. is considered to be a period of consolidation of educational technology, which has become the most commonly used term in the science of pedagogy and the educational process (Даниловић, 2004). With the application of educational technology, students can independently progress in mastering teaching materials, to choose the pace of work, to repeat the material that is not sufficiently clear, that after tests performed immediately get results and track their progress. Interactive, multimedia content provides a great advantage of modern learning over traditional learning. With the application of educational technology we get feedback between the teacher and the student.

Among the first studies on the comparison of the traditional and modern ways with the help of educational technologies research was Clark Richard (Clark, R. 1983). He tried to compare research between lectures and computer guidance and instruction to determine which the better way of learning is. $\mathrm{He}$ came to the conclusion that they are both effective depending on the ways they are used. The same conclusion came by other authors (Dynarski et al. 2007; Kulik, 2003) and that is that there are some major differences in the use of educational technology and traditional teaching. On the other hand, research at the Center for Educational Research in Pittsburgh within Individually Prescribed Instruction showed that computers are better tailored to the individual abilities of students, rather than teachers themselves. Educational technology must inevitably be integrated into classrooms and curricula (Clements and Sarama, 2003; Glaubke 2007; NAEYC and Fred Rogers Center, 2012). With the advent of educational technology in the classroom teacher, education is faced with the challenge that teachers integrate educational technology in their daily work. Numerous studies have shown that a small number of teachers is willing to integrate educational technology in their teaching activities (Becker, 2000; Hermans et al., 2008; Stošić and Stošić 2013; Wang et al., 2004). The reason is that there are two categories of teachers in the understanding of educational technology. Some of them have thorough understanding of modern technical appliances 
and their operation while others think it is necessary for them to gain additional technical knowledge of the appliances and methods, teaching methods, student-teacher relationship... These two groups represent a group of teachers between older and younger teachers. Older teachers during their study did not have the possibility of training with modern technical appliances, did not have the information technology, educational technology... while the younger generation of teachers possess the knowledge required for the use of educational technology. For a better understanding of educational technology requires a set of computer science, pedagogy, psychology, cybernetics, informatics... The knowledge teachers possess is sufficient for a basic use of education technology. However, educational technology is one big system. First of all, teachers have a basic knowledge of the use of educational technology. It takes far more professional training through a variety of conferences, courses, professional literature, seminars... in order to get a better knowledge in the use of educational technology. The fact is that under use of educational technology, primarily due to poor school equipment necessary resources, insufficient information and knowledge of teachers and the lack of interest and lack of motivation of teachers to use them. Teachers have to be motivated to use the same because the use of educational technology in teaching provides better interaction with students, better reception of information because the students receive knowledge visual, auditory and kinesthetic way. Among other things, an educational technology motivates students to work independently where the student is more motivated to return to learning and working because modern technical equipment is widely available at any given moment.

\section{CONCLUSION}

The presence of educational technology is growing in the classroom. The new generation of kids come ready to work with these new technologies, which play an important role in children's learning and acquiring various cognitive knowledge so that educational technology must be incorporated into future curricula. The application of educational technology enhances skills and cognitive characteristics. With the help of new technology comes an explosion of learning and receiving new information, especially on mobile devices.

Teachers have been using new technol- ogies in the classroom. However, the development and application of new technologies grows as a measure that is the question of whether teachers are trained to keep up with them. Here we have two problems. Are the teachers have the ability to use educational technology and whether the school is sufficiently equipped with all modern technical means? Numerous studies were carried out, some are still ongoing, but we have to find the right strategies to apply educational technology in teaching.

\section{Conflict of interests \\ Author declare no conflict of interest.}

\section{REFERENCES}

Becker, H. J. (2000). Access to classroom computers. Communications of the ACM, 43(6), 24-25.

Clark, R. E. (1983). Reconsidering the research on learning from media. Review of Educational Research, 53(4), 445-459.

Clements, D.H., \& J. Sarama. (2003). "Strip Mining for Gold: Research and Policy in Educational Technology: A Response to 'Fool's Gold."' $A A C E$ Journal, 11 (1): 7-69.

Dynarski, M., Agodini, R., Heaviside, S., Novak, T., Carey, N., Campuzano, L., Means, B., Murphy, R., Penuel, W., Javitz, H., Emery, D., \& Sussex, W. (2007). Effectiveness of reading and mathematics software products: Findings from the first student cohort. Washington, DC: Institute of Education Sciences.

Glaubke, C. R. (2007). The Effects of Interactive Media on Preschoolers' Learning: A Review of the Research and Recommendations for the Future. Oakland, CA: Children Now.

Greenhow, C., Robelia, B., \& Hughes, J. E. (2009). Web 2.0 and classroom research: What path should we take now? Educational Researcher, 38(4), 246-259.

Gutnick, A.L., M. Robb, L. Takeuchi, \& J. Kotler. (2011). Always Connected: The New Digital Media Habits of Young Children. New York: The Joan Ganz Cooney Center at Sesame Workshop. Retrieved from www.ictliteracy.info/ rf.pdf/jgcc alwaysconnected.pdf

Hermans, R., Tondeur, J., van Braak, J., \& Valcke, M. (2008). The impact of primary school teachers' educational beliefs on the classroom use of computers. Computers and Education, 51(4), 1499-1509.

Kauffman, D. F. (2004). Self-regulated learning in web-based environments: Instructional tools designed to facilitate cognitive strategy use, metacognitive processing, and motivational beliefs. Journal of Educational Computing Research, 30, 139-161.

Kulik, J. A. (2003). Effects of using instructional technology in elementary and secondary schools: What controlled evaluation studies say. SRI Project Number P10446.001. Arlington, VA: SRI International. 
(IJCRSEE) International Journal of Cognitive Research in Science, Engineering and Education Vol. 3, No.1, 2015.

Lee, H. W., Lim, K. Y., \& Grabowski, B. L. (2008). Generative learning: Principles and implications for making meaning. In M. J. Spector, D M. Merrill, J. van Merrienboer \& M. P. Driscoll (Eds.), Handbook of research and educational communications and technology (3rd ed.). New York, NY: Taylor \& Francis Group.

Leu, D. J., O’Byrne, W. I., Zawlinski, L., McVerry, G., \& Everett-Cacopardo, H. (2009). Expanding the new literacies conversation. Educational Researcher, 38(4), 264-269.

Lowther, D. L., Inan, F. A., Ross, S. M., \& Strahl, J. D. (2012). Do one-to-one initiatives bridge the way to 21 st century knowledge and skills?. Journal of Educational Computing Research, 46(1), $1-30$.

Morrison, G. R., Ross, S. M., Kemp, J. E., \& Kalman, H. (2010). Designing effective instruction: Applications of instructional design $\left(6^{\text {th }}\right.$. Ed. $)$, New York, NY: Wiley.

NAEYC \& Fred Rogers Center for Early Learning and Children's Media (2012). Technology and Interactive Media as Tools in Early Childhood Programs Serving Children from Birth through Age 8. Joint position statement. Washington, DC: NAEYC; Latrobe, PA: Fred Rogers Center for Early Learning at Saint Vincent College. Retrieved from www.naeyc.org/files/naeyc/file/ positions/PS_technology_WEB2.pdf

Pedagoški leksikon̄ (1996). Beograd: Zavod za udžbenike i nastavna sredstva.

Rideout, V. (2011). Zero to Eight: Children's Media Use in America. San Francisco, CA: Common Sense Media. Retrieved from www.commonsensemedia.org/sites/default/files/research/zerotoeightfinal2011.pdf

Stosic, L., \& Stosic, I. (2013). Diffusion of innovation in modern school. International Journal Of Cognitive Research In Science, Engineering And Education (IJCRSEE), 1(1), 5-13. Retrieved from http://ijcrsee.com/index.php/ijcrsee/article/ view/7

Wang, L., Ertmer, A. P., \& Newby, J. T. (2004). Increasing preservice teachers' self-efficacy beliefs for technology integration. Journal of Research on Technology in Education, 36(3), 231-250.

Даниловић, M. (2004). Recognition and development of "educational technology" as a scientific field and school subject, Zbornik Instituta za pedagoska istrazivanja, (36):106-121, DOI:10.2298/ZIPI0436106D 